\title{
Historein
}

Vol 4 (2003)

Public Histories

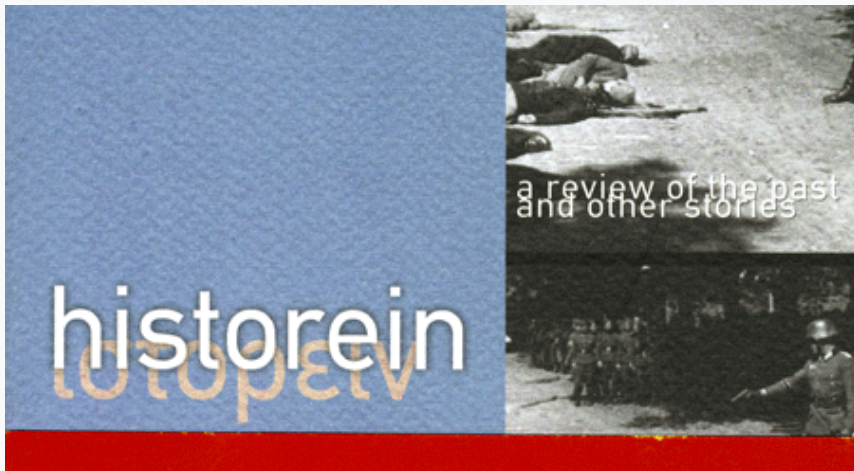

\section{Changing Frames of Historiography: Cappadocian Stories}

\author{
Ioanna Petropoulou
}

doi: $10.12681 /$ historein.89

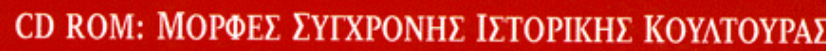

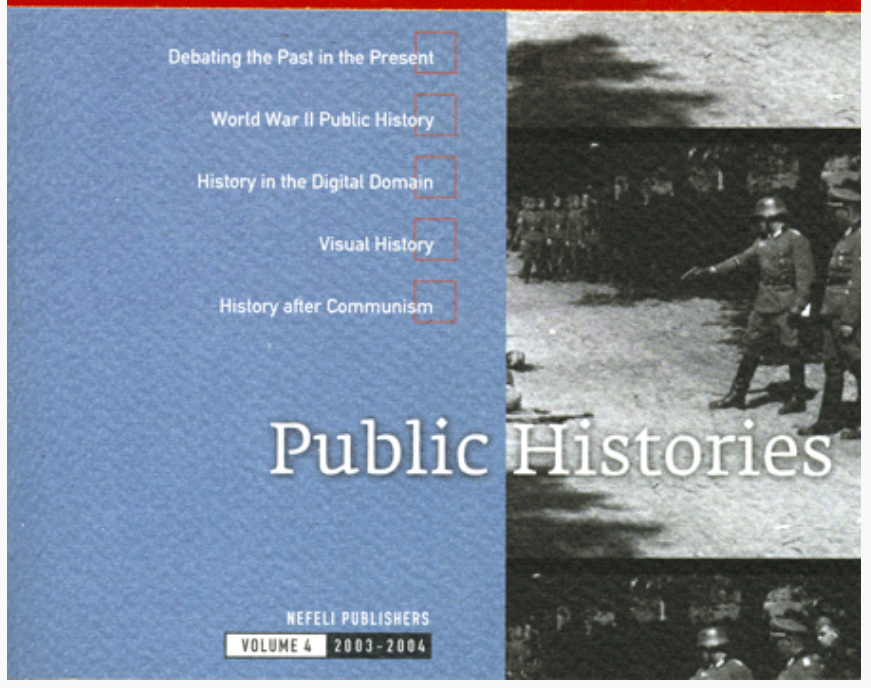

\section{Copyright ( 9 2012, loanna Petropoulou}

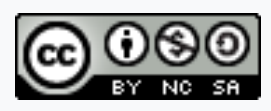

This work is licensed under a Creative Commons Attribution-NonCommercialShareAlike 4.0.

To cite this article:

Petropoulou, I. (2004). Changing Frames of Historiography: Cappadocian Stories. Historein, 4, 206-213. https://doi.org/10.12681/historein.89 


\section{Changing \\ Frames of \\ Historiography: \\ Cappadocian \\ Stories}

by Ioanna Petropoulou

\section{Introduction}

The purpose of this article is to discuss the historiographical strategies developed during the $19^{\text {th }}$ century by the Orthodox intellectuals of the Levant, and more specifically, the Ottoman Empire. I would like to begin by making three preliminary remarks which, I believe, will help situate the subject of this article:

1. When speaking about the Orthodox subjects of the eastern Ottoman Empire, one has to keep in mind that, though almost entirely Greek-Orthodox in its religious beliefs, that population was not always Greek-speaking. In a century dominated by dissemination of the "national" idea, historiography developed along specific lines. During the first half of the $19^{\text {th }}$ century the writing of history was characterized by the ideals of the pre-national/religious world of ecumenism, whereas after 1850 history was interpreted in terms of the nation-states coming into being.

2. I focus here on a process I call the "hellenization" of a region that resulted in what the

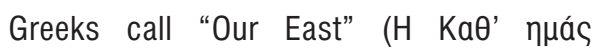
Avatoגń). This movement toward "hellenization" on the linguistic and ideological level was part of the movement known in modern

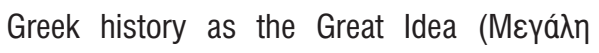
I $\delta \varepsilon \dot{a})$. In the eastern Ottoman provinces during the $19^{\text {th }}$ century the effort to produce a written interpretation of the past, both as a collective demand and as a historiographical act, was directly related to this specific campaign aided at creating a Greek national consciousness.

3. During the last decades of the $19^{\text {th }}$ century the production of secular local history by Greek-Orthodox intellectuals in the Ottoman 
East was either characterized by a Greek national orientation or did not exist. It was precisely this national orientation that made its production feasible.

At this point, I would like to pose three questions about producing printed history:

1. What was the prevailing model, the predominant paradigm, forming the basis on which history was written? The Orthodox East was called upon to relate its history by adapting it to a borrowed, theoretical/interpretive model originating in mainland Greece.

2. Who were the authors, the performers of this history-writing activity? In terms of their position in the social pyramid, their profile changed over time.

3. What historiographical strategies were devised to analyze primary sources? Since the material was treated in accordance with a given/borrowed paradigm, the writing process had to respond and conform to an intrinsically contradictory historiographical effort.

\section{The Contradictory Effort}

The model was a direct outcome of the nation-state ideology. It was imbued with the national viewpoint of history and was intended to produce a narrative written in the national/Greek language. An attempt was made to graft this "national" product onto the pre-national world of the Ottoman Empire, where identity was based on religion and not nationality. The effort to create a "Greek" national consciousness through a campaign of hellenization targeted population groups that shared the same religion with Greece proper yet spoke other languages, especially Turkish. The Turkish-speaking Orthodox population had their own communications network, and in the large urban centers inhabited their own neighborhoods, specialized in certain occupations, including owning printing shops. Above all, they had their own distinct way of writing and their own literature in the Karamanli script (i.e. Turkish written using the Greek alphabet).

For the Christian communities of Ottoman Anatolia the writing of history evolved along three parallel routes. The first route led to processes of self-identification. The second route was characterized by the transition from what used to be an ecclesiastical education controlled and disseminated by clerics to a secularized education provided by laymen. Last but not least, the third development was a transition from the history of the few, i.e. of the leaders, and written by high-ranking officials, to the history of the many, a history written on a broader social base by a class of people who appeared for the first time on the publishing scene. The act of writing history passed down into the hands of a more numerous body of people, the so-called middle classes. I call this phenomenon that developed during the $19^{\text {th }}$ century the "democratization of writing."

\section{Processes of Self-Identification}

For a long period - roughly coinciding with the decade immediately before the Greek War of Independence, which erupted in 1821, and also including ten years after its end in 1827 - it was scholars outside the Orthodox community who supplied the reading public with historical infor- 
mation about the Christians of the East. Historical knowledge about the "Levant," then, was produced more or less in the absence of the people who lived in those territories, since it was largely monopolized by Western travelers - mostly English, French, or Germans. During this period the native Christian inhabitants of the Levant allowed themselves to be defined by others. In other words, they allowed others to write their history and remained objects rather than subjects of their own historical narrative. Western visitors on exploratory or diplomatic missions were the agents recording and reporting on the present as well as the past of the Levantine populations the prerogative of written expression resided with them. Imported as foreign literature either in their original language or in its modern Greek translation, those travellers' accounts operated as a database, a "safekeeping" of knowledge to be accepted or rejected in the decades to come. It is, after all, well known that before and after the Greek War of Independence, knowledge about ancient and contemporary Greece was also "imported," reaching the bookish, scholarly public of the Orthodox East most frequently through European cultural channels.

The Orthodox world of the eastern Ottoman Empire did not produce locally-written history during the 1830s, the first decade after the modern Greek state was founded. In fact, very few historical works were published from the late $18^{\text {th }}$ century on, in very few urban printing shops, mainly in the coastal towns. These works were written by scholars who did not necessarily belong to local society, since they themselves were products of the major urban cultural centers. Their exceedingly few works are the exceptions that prove the rule.

These first attempts to write history in the Orthodox East were of a dual nature and recorded the transition from tradition to modernity. Even though these publications were written by the clergy, in terms of their subject matter they tended to have urban, secular themes, like the reconstruction of the history of an outstanding town rather than the description of a monastery.

In this sense, they pinpoint the beginning of what is known in the literature as the period of "selfidentification." In the period leading to the secularization of the $19^{\text {th }}$ century, the Orthodox subjects of the empire gradually made the transition from being the objects of interpretation (i.e. from being written about) to being the interpreting agents, the ones who tracked their community's historical progress, the creators of its written history. At this new historical conjuncture, senior clerics, patriarchs, and metropolitans wrote essays mainly topographical in nature. Depending on the writer, the works are sometimes imbued with religious and ecumenical views and sometimes with a secular, Enlightenment attitude. Yet in all cases they are characterized by a pre-national ideological viewpoint.

A little later, in mid-century, the writing and printing of historical works changed hands as the intelligentsia became gradually more independent of the Church. The managerial classes and senior state functionaries now assumed the burden of narrating history. A new class of educated people came into being, flooding the cities and large urban centers. They constituted society's bourgeoisie in the double meaning of the word: they lived within the densely populated urban environments that defined them both culturally and in terms of occupation, and at the same time they 
belonged to a particular social stratum of middle-class scholars. This was the budding, relatively small bourgeois intelligentsia that began to form a "circle of fellows." Even when they did not actually represent authority, these bourgeois scholars always moved within the world of power. It was precisely because of their association with power that they had access to knowledge, they could read and compare sources, and they had the privilege of learning languages, living and dead, European and Asian. Anyone who could claim to have the qualifications that enabled him to speak about the past dominated culture, and in doing so helped support the secular power. It follows, then, that the act of writing was still a socially determined function, finite, if not closed.

\section{The Democratization of Writing}

The national "self-identification" of the Eastern Christians did not take place in a vacuum but rather materialized in tandem with similar developments experienced by their co-religionists and the other religious communities, the so-called millets, living in the Ottoman Empire. The Hellenic Literary Society of Constantinople (HLSC), established in the early 1860s, provides a good example. The society was established to create a Greek-speaking body of intellectuals outside the confines of the Church, and as such it operated on many cultural levels. It is not my intention here to analyze its wide-ranging historical contribution, but only to stress that this was the first attempt to form "organic intellectuals," in the Gramscian sense, in a secular organization. Although the society was established after the fledgling Greek state, it acted outside the frontiers of that state, addressing itself to "unredeemed Hellenism," i.e. the Greek irredenta still within the confines of the Ottoman Empire.

The society accepted texts from any member of the Greek-speaking community, thereby making even the most geographically isolated history researcher or Greek language teacher a potential historian. This opened the gates of historical writing, laying the theoretical foundations for a national historiography to which ever larger numbers of people could contribute. The policies the society adopted during its long life to achieve its primary goal of promoting Greek secular intellectual life have not yet been researched even though they deserve thorough examination.

Self-identification, secularization, and nationalism were all elements in a chemical reaction which begun in the environment created by the Ottoman Tanzimat reforms. The remarkable increase in production of historical knowledge during the last two decades of the $19^{\text {th }}$ century was not caused by imposition of a distinctly "Greek" national outlook upon the reconstruction and interpretation of history, but this national historiographical perspective probably was the inspiration for increasing numbers of authors. The process of writing history intensified in the new environment, remarkably increasing the number of local histories published in Greek.

\section{History-Writing by the Orthodox Community}

The drive to conceive - on a theoretical level - and subsequently write a purely Greek-oriented national history for and by the Orthodox subjects of the Ottoman Empire gave rise to significant 
difficulties. Not professionally trained historians, these new writers of this history quickly came face to face with the problem of how to deal historically with the centuries of Ottoman rule.

To begin with, this problem was associated with the authors' very concrete, Ottoman, present. The existence - particularly in the Anatolian hinterland - of a large body of Turkish speakers within the empire's Orthodox population seriously complicated production of a Greek-oriented, "national" historiography.

This problem was related to the past, and more specifically to the historical treatment of the Ottoman past. As subjects of the Ottoman Empire, the fledgling historians of this new, national history had to perform a dual task. They had to both provide an historical explanation for the existence of old-style co-religionists and the very real Turkish-speaking Orthodox populations of the hinterlands and also perform the missionary duty of retrospectively integrating those populations into the imaginary framework of a freshly minted, Greek-oriented national ideology.

In this case, the fundamental tenet of romantic historiography, i.e. the notion of uninterrupted continuity in the historical trajectory of Hellenism (otherwise known as the three-period model of Greek history), was conceived by Konstantinos Paparrigopoulos [1815-1891], the national historian par excellence, professor at the University of Athens. Born in Constantinople, Paparrigopoulos relied upon a romantic interpretation of history to paint an imaginary canvas he later used to organize his primary material. Yet his attempt to transform the Greek national myth in the Ottoman Empire into a model for writing history ended up working in two contradictory ways. The transformation acted as a catalyst, accelerating the writing of historical works, but it also became a rigid template, curbing and at times even stifling the writing of history. Paparrigopoulos's methods brought about a number of historiographical adjustments and gave birth to varying strategies for reconstructing the national past.

\section{Three Time Periods and Silence}

Members of the Orthodox intelligentsia interested in history were obliged to select the periods with which they were concerned, and these selections reflected their historiographical strategies. They tended to make one of the following four main choices in dealing historically with the Ottoman past.

\section{Pagan/Pre-Christian}

By concentrating on a distant antiquity, writers were freed from having to deal with anything Ottoman. The emphasized the timeless nature of Greek culture, which experienced exceptional development along the western coast of Asia Minor. They exalted what they perceived as the cultural purity of Hellenism and in doing so occasionally borrowed racial theories, such as Gobineau's, from the West.

\section{Early Christian/Byzantine}

The early Christian and Byzantine centuries was the privileged period for the Greek language. By definition, an educated individual during this period spoke Greek. In addition, study of this period 
was primarily concerned with Greek Orthodoxy. Eventually this period became the cornerstone of Greek national historiography, since it linked Orthodoxy with the Greek world.

\section{Ottoman/Patriarchal}

Those writers who focussed on Ottoman rule and the history of the Ecumenical Patriarchate saw events exclusively in light of the patriarchate's history, dealing with the evolution of leading groups within the Church. Naturally, in accounts about this period the religious, pre-national character of the past prevails. Historians of this period made no attempt to suppress the 0ttoman factor. On the contrary, they portray the Great Church in its natural historical environment of the Ottoman Empire. Acknowledgments of any national Greek factor are marginal.

\section{Karamanli Silence}

At first sight, the silence of Turkish-speaking Christians writing Turkish in the Greek alphabet when the demand for national historiography was at its peak seems a historiographical poverty, a literary deficiency. Karamanli writing and publishing increased spectacularly in the second half of the $19^{\text {th }}$ century, but not Karamanli writing of and publishing of history. This clearly was a choice. The new secularized intelligentsia of the Turkish-speaking Orthodox community within the Ottoman Empire deliberately refused to fall in line with the demand that history be written from the Greek point of view; it refused to betray its own pre-national identity.

\section{The 1922 Turning Point and the Scholars Remaining in Constantinople}

In early $20^{\text {th }}$ century Asia Minor, these four distinct historiographical tendencies developed along different trajectories, intensifying the national and nationalistic character of writing history. With various modifications and selective use of primary sources, the romantic model propagated by Paparrigopoulos was put into rudimentary operation. Despite the lack of professional historians, the number of amateur historians championing the national idea kept growing, as did the polarization between Greek and Turkish nationalism. As the landmark year of 1922 approached, the number of papers and books on local history proliferated.

The end of the extensive Christian presence in what the Greeks called "Our East" did not necessarily mean that the historiography under discussion ended. Written reconstructions of the past have continued to be produced. Despite the mandatory exchange of populations in 1923, a small Greek community was allowed to remain. Some intellectuals within this community, mostly history-loving scholars living in the Phanar district of Constantinople, continued to study regions rich in archaeological findings and Christian religious artifacts. The articles and books they wrote about local history focussed mainly on the Byzantine past, and their publications preserved the history of many places despite rapid changes. This specific kind of historiography continued to be produced in Constantinople - in Stambul, as the title pages of those Greek books indicated even after the 1923 exchange of populations. Most of these works were written in the archaic form of the Greek language (katharevoussa). 


\section{Continuation and Refugees}

Democratization of the writing of history has continued. After the exchange of populations, the history of both classical antiquity and Byzantium were retrospectively reinstated in Greece as well, thanks to a proliferation of historical works written by scholars newly arrived from what used to be Ottoman Anatolia. This new historiography tended to fragment the past by gradually focussing on ever smaller geographical units histories were written first about regions, then about cities, and, finally, about villages. On the theoretical level, Paparrigopoulos's reading of history provided the writers of history with the national historiographical model, which was now applied without resistance. As the newly arrived refugees became integrated into modern Greek society, they identified with the established national ideology of the state that took them in.

Democratization of the writing of history was fully accomplished when the mediation of an interpretive text was no longer required for reconstructing the past. I am referring here to refugee accounts, for which no second-party author is needed between the writer and the events being described. The places remembered were regained and re-created by directly involved individuals. In terms of methodology, after 1922 history was equated with memory, and the writing of history no longer was the product of erudition and discipline. Instead, it was generated by tragedy and the consequent outpouring of oral accounts. Witnesses of war related their own experiences. Oral history accounts came to be valued because they were first-hand reports. These oral accounts came to replace the voluminous written reports on which the historiography of this period had previously relied.

The Center for Asia Minor Studies (CAMS) was established in the late 1920s after the influx of one and a half million refugees into Greece. The center was first run by two scholars with complementary specializations: Melpo Logotheti, a Greek musicologist who had studied in Europe under Hubert Pernot at the Institut Neohellenique in Paris; and Octave Merlier, a French intellectual steeped in the culture of Greece. They spearheaded an effort to record oral history accounts given by ordinary people. In this case, the motivation to do "history from below" - this "child of the French revolution," in Hobsbawm's words - came from quite specific circumstances. The Western cultural tradition that shaped the center's pioneering researchers and provided them with a kind of belated Orientalism with which to study the East intersected with another tradition of native, modern Greek historical sensitivity. The contemporary Greek intelligentsia, influenced by the politically leftist movements, the movement of demoticism and the development of ethnography, all prominent throughout the $20^{\text {th }}$ century, has recognized the testimony of the rural population as genuinely authentic.

Treating "the language of the people" as a model worthy of admiration, the center set out to compile a history from below, to experiment. After the end of World War II and the Greek Civil War, the center sought out refugees from Asia Minor with primary school education and invited them to write history, after which the center organized these accounts geographically. For encouragement, the center provided the refugees with "the means of production," a pencil and notebook, 
as well as an optional questionnaire to use as a guide. The center turned to men and women alike, including people who, because of their socio-economic backgrounds, had no experience with writing.

These marginally literate people had never considered addressing an audience beyond their immediate family, either orally or in writing, but they nonetheless wrote their own histories down, without recourse to any other sources of information. In a sense, the Center for Asia Minor Studies "proletarianized" the writing of history, for certainly there was no precedent for such "proletarianization" in Greece. More important is that it gave ordinary people a voice, the right to express themselves, the right to write, which they would not otherwise have had.

Note: The following list of occupations is a sample of the professional diversity of the group of people whose manuscripts are kept at the Center for Asia Minor Studies. The list includes the year the manuscript was written as well as the author's place of residence.

\begin{tabular}{|c|c|c|}
\hline 1952 & laborer & Korydallos, Athens \\
\hline 957 & farmer & Florina \\
\hline 59 & cantor & Brahami, Athens \\
\hline 60 & $\begin{array}{l}\text { egg-seller/ } \\
\text { chicken-farmer }\end{array}$ & Vrilissia, Athens \\
\hline 61 & $\begin{array}{l}\text { retired S.E.K. } \\
\text { (Greek National } \\
\text { Railways) employee }\end{array}$ & Xanthi \\
\hline 62 & coffee-shop owner & $\begin{array}{l}\text { Nea Smyrni, } \\
\text { Athens }\end{array}$ \\
\hline 62 & farmer & $\begin{array}{l}\text { Pontolivado, } \\
\text { Kavala }\end{array}$ \\
\hline ? & $\begin{array}{l}\text { worker } \\
\text { in lime-production }\end{array}$ & Xanthi \\
\hline 1962 & farmer & Khalkiades, Farsala \\
\hline 1963 & baker & Nea Ionia, Athens \\
\hline 65 & $\begin{array}{l}\text { convenience-store } \\
\text { owner }\end{array}$ & Katerini \\
\hline 1974 & farmer & $\begin{array}{l}\text { Tefili, Monofasion, } \\
\text { Crete }\end{array}$ \\
\hline
\end{tabular}

* The paper was presented at the "4th International Conference on the History of Historiography in Modern and Contemporary Greece, 1833-2002" and has retained its oral form. 